\title{
Radiation utilization efficiency and evaporative fraction of rainfed rice in eastern India
}

\author{
GOURANGA KAR and ASHWANI KUMAR \\ Indian Institute of Water Management, Bhubaneswar - 751023, Orissa, India \\ Email:kar_wtcer@yahoo.com
}

\begin{abstract}
Optimum utilization of photosynthetically active radiation (PAR) along with proper nitrogen management for sustainable rice production is still a promising management recommendation in order to increase profit for the low income rice farmers of the eastern India. The objective of this investigation was to relate the cumulative development of above ground dry biomass to cumulative absorbed photosynthetically active radiation (APAR) of 2 rainfed rice varieties ('Lalat' and 'Gayatri') with 3 nitrogen levels $\left(50,100\right.$ and $\left.130 \mathrm{~kg} \mathrm{ha}^{-1}\right)$ under tropical monsoon climate of the region. Averaged over yeas and nitrogen level, radiation utilization efficiency in terms of above ground dry biomass (REUbio) of 1.88 ( \pm $0.08)$ and $2.06( \pm 0.09) \mathrm{gMJ}^{-1}$ were recorded for the cultivar 'Lalat' and 'Gayatri', respectively. Higher dose of nitrogen increased the RUE significantly, averaged over years and varieties, mean values of it (RUE ${ }_{\text {bio }}$ ) were $1.68( \pm 0.10), 2.04( \pm 0.09)$ and $2.19( \pm 0.08) \mathrm{gMJ}^{-1}$ under 50,100 and $130 \mathrm{~kg} \mathrm{ha}^{-1}$ nitrogen respectively. The ratio of the latent heat flux to the available energy or evaporative fraction was found to be $79-82 \%$ in different cultivars and seasons. Partitioning of evapo-transpiration (ET) indicated that about $70-80 \%$ of seasonal ET came from transpiration.
\end{abstract}

Key words: Radiation utilization efficiency, Energy balance, Rice, Tropical Monsoon climate

In eastern India $78 \%$ rainfed rice is grown during rainy season under tropical monsoon climate when sky remains cloudy for most of the time. Poor rainfed farmers of the region also grow the crop with sub-optimal nitrogen fertilizer. Optimum utilization of photosynthetically active radiation (PAR) along with proper soil fertility particularly nitrogen management for sustainable rice production is still a promising management recommendation in order to increase profit for the low income rice farmers of the region. Deficit nitrogen restricts root systems and plant growth; too much nitrogen can delay maturity and causes excessive vegetative growth at the expense of grain yield. Growth and yield of any grain crop again is largely determined by radiation interception, the efficiency of conversion of intercepted radiation to dry matter and partitioning of dry matter to grain. (Kar, 2005; Figuerola and Berliner, 2006). These radiation utilization efficiency and energy balance characteristics of grain crops are well established in different parts of the world from unstressed field experiments for wheat (Kiniry et al., 1989; Gregory et al., 1992), maize (Sivakumar and Virmani 1984), barley (Gallaghar and Biscoe, 1978), pigeonpea (Robertson et al., 2001; Hughes and Keatinge., 1983), sunflower (Conner et al., 1985). For rainfed rice crop in eastern India, still there is a paucity of such type of information where rice is grown under suboptimal nitrogen management during south west monsoon season and when the sky remains cloudy for most of the growth period. Keeping the importance of above points in view, radiation utilization efficiency of 2 rainfed rice varieties under 3 nitrogen levels $\left(50,100\right.$ and $\left.130 \mathrm{~kg} \mathrm{ha}^{-1}\right)$ were investigated in relation to total above ground dry biomass and grain yield production.

\section{MATERIALS AND METHODS}

Experiment was carried out at Pipli, Puri, Odisha during rainy seasons of 2008 and 2009. The climate is typically tropical monsoon type with long-term mean annual rainfall of $1440 \mathrm{~mm}$ and $70-75 \%$ of rainfall occurs during southwest monsoon period (June-September). Soils were moderately acidic in reaction, non-saline and had moderate organic carbon content, $\mathrm{pH}$ ranged from 6.3 at $0-0.15 \mathrm{~m}$ depth to 6.1 at $0.30-0.45 \mathrm{~m}$ depth. The texture varied from clay to heavy clay with higher bulk density $\left(1.46 \mathrm{Mg} \mathrm{m}^{-3}\right.$ at $0-0.15 \mathrm{~m}$ depth to $1.59 \mathrm{Mg} \mathrm{m}^{-3}$ at $0.90-1.20 \mathrm{~m}$ ). The soil moisture retention at permanent wilting point $(0.15 \mathrm{MPa})$ ranged between $0.162 \mathrm{~m}^{3} \mathrm{~m}^{-3}$ at $0-0.15 \mathrm{~m}$ depth and $0.210 \mathrm{~m}^{3} \mathrm{~m}$ ${ }^{3}$ at $0.30-0.45 \mathrm{~m}$ depth. The soil moisture retention at field capacity $(0.033 \mathrm{MPa})$ varied from $0.401 \mathrm{~m}^{3} \mathrm{~m}^{-3}$ at $0-0.15 \mathrm{~m}$ depth to $0.518 \mathrm{~m}^{3} \mathrm{~m}^{-3}$ at $0.30-0.45 \mathrm{~m}$ soil depth. The organic 
carbon in the soil profile ranged from $6.25 \mathrm{~g} \mathrm{~kg}^{-1}$ at $0-0.15 \mathrm{~m}$ depth to $4.25 \mathrm{~g} \mathrm{~kg}^{-1}$ at $0.90-1.20 \mathrm{~m}$ depth.

The on-farm trial was conducted in split plot design with 3 replications. The treatments were 2 varieties of rice $\left(\mathrm{V}_{1}=\right.$ 'Lalat', $\mathrm{V}_{2}=$ 'Gayatrii') in main plots and three levels of nitrogen $\left(\mathrm{N}_{1}=50 \mathrm{~kg} \mathrm{Nha}^{-1}, \mathrm{~N}_{2}=100 \mathrm{~kg} \mathrm{Nha}^{-1} ; \mathrm{N}_{3}=130 \mathrm{~kg}\right.$ $\mathrm{N} \mathrm{ha}^{-1}$ ) in subplots. In each year, rice was transplanted on last week of July with plant to plant and row to row distance of $0.15 \mathrm{~m}$ and $0.20 \mathrm{~m}$, respectively. Phosphorus and Potassium were used at the rate of $50 \mathrm{~kg} \mathrm{ha}^{-1}$ in all plots. Full dose of $\mathrm{P}$ and $\mathrm{K}$ and $1 / 3^{\text {rd }}$ of $\mathrm{N}$ were applied as basal. The remaining $\mathrm{N}$ fertilizer was applied at tillering and panicle initiation stages in two equal splits. Other crop management practices like weeding, intercultural operations were performed using standard agronomic package of practices. Plant samples were collected from five plants at active tillering, end of effective tillering, panicle primordia initiation, booting, heading/flowering/panicle initiation/anthesis, milky, dough, yellow ripe, maturity stages of the crop for measuring leaf area index and above ground dry biomass. The rate of increase of biomass density, $\mathrm{B}\left(\mathrm{g} \mathrm{m}^{-2}\right)$, is proportional to the absorbed flux density of photosynthetically active radiation (PAR), (MJ m $\left.{ }^{-2} \mathrm{~d}^{-1}\right)$ and APAR is some fraction, $\mathrm{f}$ of the incident radiation on the canopy from above, Io $\left(\mathrm{MJ} \mathrm{m}^{-2} \mathrm{~d}^{-}\right.$ 1) (Monteith, 1977 ; Pitman, 2000):

$\frac{d B}{d T}=\varepsilon A P A R=* f *$ Io

Where $\varepsilon$ is the radiation use efficiency (RUE) $\left(\mathrm{g} \mathrm{MJ}^{-1}\right)$, which is the ratio between the accumulation of biomass and accumulation of absorbed photosynrhetically active radiation (APAR) by plant canopies..

$\varepsilon\left(\mathrm{g} \mathrm{MJ}^{-1}\right)=\frac{\sum B(\mathrm{~g} \mathrm{~m}-2)}{\sum A P A R(M J m-2)}$

Cumulative biomass can be obtained by integrating equation (1):

$B=\int_{o}^{t} \varepsilon$ flo $d t=B o+\varepsilon A P A R$

Where APAR is the cumulative absorbed PAR flux density and Bo is the biomass density at time zero. Regression of B vs. APAR should a linear regression line of slope and intercept zero, if no biomass is present prior to the start of photosynthesis (Pitman, 2000). The first field confirmation of this linear relationship between $B$ and was given by Gallaghar and Biscoe (1978) for cereals and has since been shown to be applicable to a wider range of crops (Russel et al., 1989; Monteith, 1994).

In this study, the mean daily values of solar radiation received above the crop canopy during different weeks of the crop growth were estimated using Penman (1948) formula and the photosynthetically active radiation (PAR) was calculated by multiplying it with 0.48 following Monteih (1972) and Kailasanathan and Sinha (1984).

The weather parameters during the crop growth period were collected from nearby meteorological observatory of Deras farm of Indian Institute of Water Management, Mendhasal, Khurda.

A dimensionless parameter, evaporative fraction $(E F)$ was used to characterize surface energy partitioning. $E F$ is defined as

$E F=\left(\frac{L E}{R_{n}-G}\right)$

$\mathrm{R}_{\mathrm{n}}$, the net radiometer was measured using BABUC $M$ net radiometer where the hemispherical polyethylene windshield domes protect the net radiometer sensor devices. $\mathrm{G}$ was computed with the equation, $\mathrm{Gs}=0.4 * \mathrm{R}_{\mathrm{n}}(\operatorname{Exp}$ ($\left.\mathrm{K}^{*} \mathrm{LAI}\right)$ ), where ' $\mathrm{Ke}$ ' is the extinction coefficient, $\mathrm{LAI}=\mathrm{Leaf}$ area index (Kar and Kumar, 2007). Experiments show that the value of $\mathrm{Ke}$ is between 0.45 and 0.65 for paddy field, nearly equal to the extinction coefficient of net radiation within a rice canopy (Uchijima 1976).

An empirical equation described by Uchijima (1961) was used to separate the daily ET into daily evaporation rate $\mathrm{E}\left(\mathrm{mm} \mathrm{d}^{-1}\right)$, and daily transpiration rate $\mathrm{T}\left(\mathrm{mm} \mathrm{d}^{-1}\right)$ using the following

equation:

$T=E T[1-\exp (-K e \times L A I]$

where $\mathrm{L}$ is $\mathrm{LAI}$, and $\mathrm{K}_{\mathrm{e}}$ is the extinction coefficient. Extinction coefficient of rice crop was taken as 0.50 for this study.

Three sets of temperature, wind velocity and humidity sensors were installed inside the cropped field on a tower at $0.5 \mathrm{~m}$ interval which measures temperature, relative humidity and wind velocity at 1 -hour interval at 3 different heights. The recorded output of all the sensors were downloaded with the help of a PC and analysed.

Analysis of variance (ANOVA) of crop and instrumental observations data were done using SAS 9.3 package. The significant differences between treatments were determined using Fisher's unrestricted least significant difference at $\mathrm{P}=0.05$ following the methodology of Gomez and Gomez (1984). 

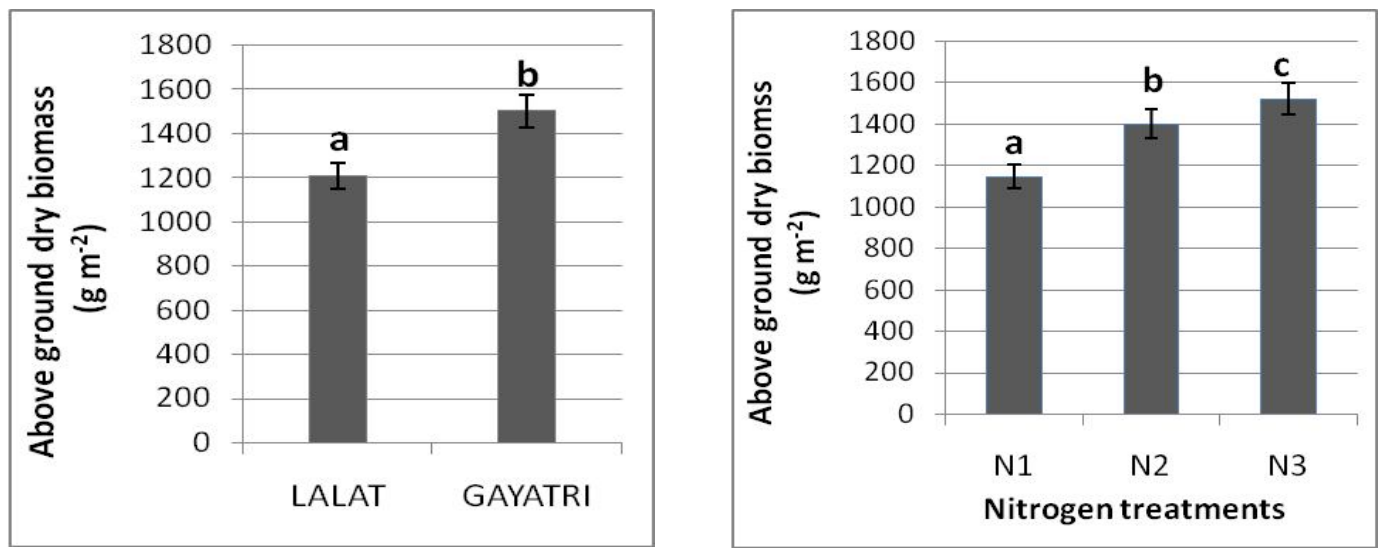

Fig. 1: Above ground dry biomass in rainfed rice as varied by varieties and nitrogen treatments
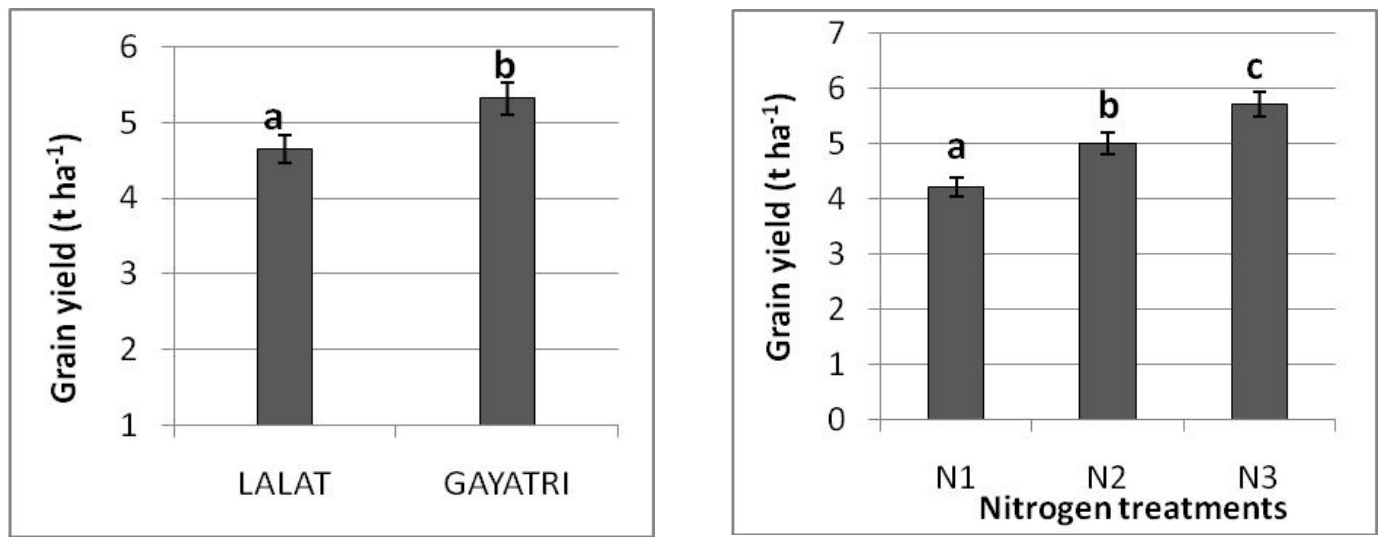

Fig. 2: Grain yield in rainfed rice as varied by varieties and nitrogen treatments

\section{RESULTS AND DISCUSSION}

\section{Above ground dry biomass, grain yield and accumulated photosynthetically active radiation}

The above ground dry biomass was recorded at different important phenological stages and peak values of it as influenced by variety and nitrogen levels are presented in Fig.-1. The above ground dry biomass (AGDB) production increased steadily after crop establishment until maturity in all the treatments. In regard to varieties, the peak AGDB production was found to be significant between 'Gayatri' and 'Lalat'. Lalat accumulated statistically lesser peak AGDB $\left(12.08\right.$ tha $\left.^{-1}\right)$ as compared to 'Gayatri' variety which recorded peak drybiomass of 15.03 tha $^{-1}$. Total dry matter production responded positively to nitrogen application too. Averaged over verities and seasons maximum AGDB accumulated to a value of $15.2 \mathrm{tha}^{-1}$ in the $\mathrm{N}_{3}$ treatment $\left(130 \mathrm{~kg} \mathrm{~N} \mathrm{ha}^{-1}\right)$ followed by $\mathrm{N}_{2}\left(100 \mathrm{~kg} \mathrm{~N} \mathrm{ha}^{-1}\right)$ that accumulated AGDB of $14.01 \mathrm{tha}^{-1}$. Minimum AGDB $\left(11.46 \mathrm{tha}^{-1}\right)$ was achieved when $60 \mathrm{~kg} \mathrm{~N} \mathrm{ha}^{-1}$ was applied.

Between two varieties, maximum grain yield (5.32 tha $^{-1}$ ) was recorded in 'Gayatri', whereas the variety 'Lalat' produced grain yield of 4.65 tha $^{-1}$ which was statistically significant. (Fig.-2). Results also showed that with increased nitrogen levels, grain yield was increased significantly. In our study, plots fertilized with $50 \mathrm{~kg} \mathrm{~N} \mathrm{ha}^{-1}$ produced significantly less grain yield $\left(4.22 \mathrm{t} \mathrm{ha}^{-1}\right)$ as compared to plots fertilized with higher dose of nitrogen $(100$ and $130 \mathrm{~kg}$ $\left.\mathrm{N} \mathrm{ha}^{-1}\right)$.

The cumulative absorbed photosynthetically active radiation (APAR) was computed as per the methodology and mean results of two study years (2008 and 2009) are presented in Fig.3. Maximum APAR of $745 \mathrm{MJ} \mathrm{m}^{-2}$ was computed during crop growth period of 'Gayatri'. The total AGDB accumulation was found to be linearly related with the cumulative absorbed PAR with the $\mathrm{R}^{2}$ value of 0.84 .

\section{Radiation utilization efficiency in terms of total biomass}

The Radiation Utilization Efficiency (RUE) in terms of AGDB (RUEbio) was computed as per the procedure mentioned in materials and methods and the relationship between total above ground dry biomass and RUE is presented in Fig.-4. The total dry matter accumulation was linearly related with the RUE in terms of biomass with the $\mathrm{R}^{2}$ 


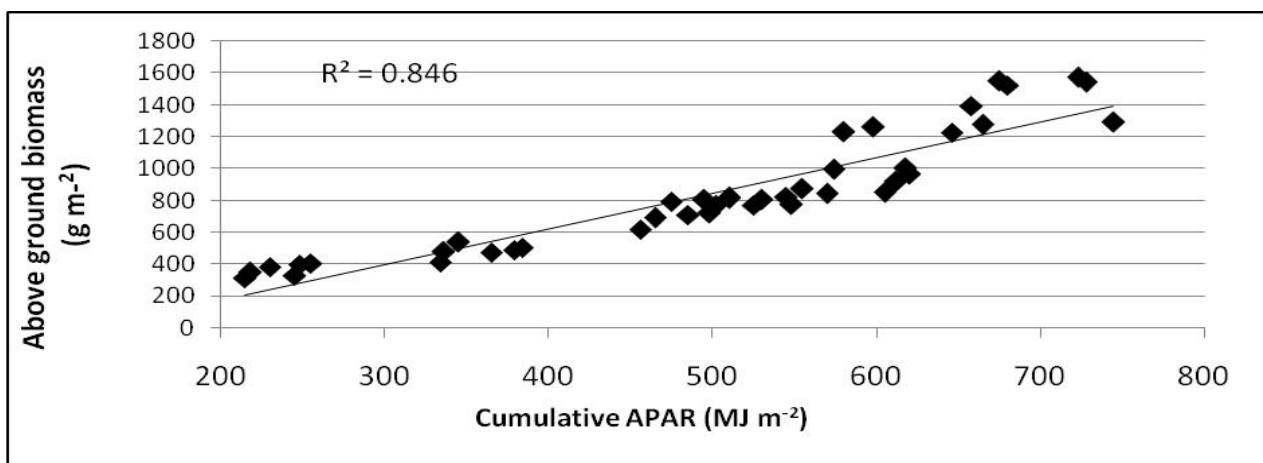

Fig. 3: Relationship between cumulative APAR and dry biomass

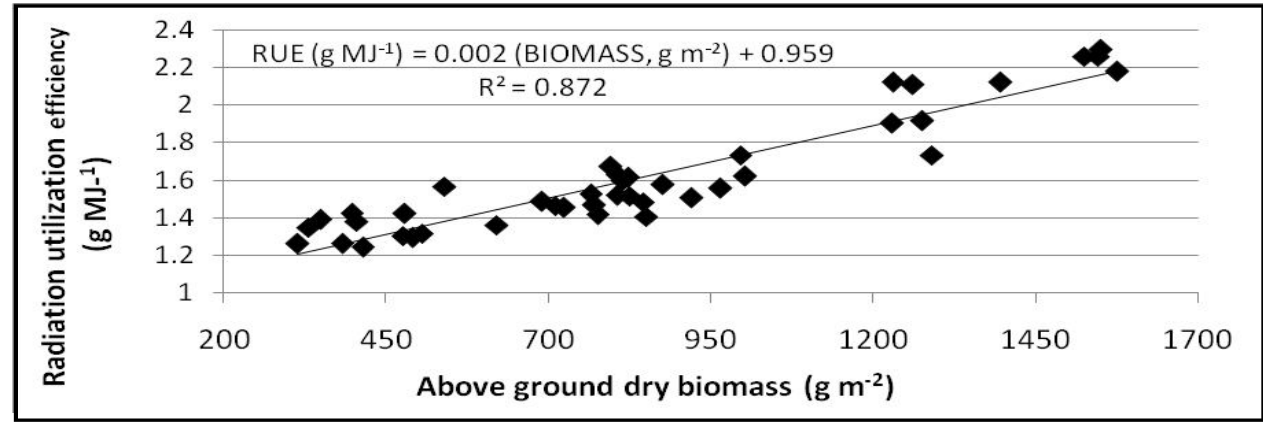

Fig. 4: Relationship between total above ground dry biomass and radiation utilization efficiency in rainfed rice
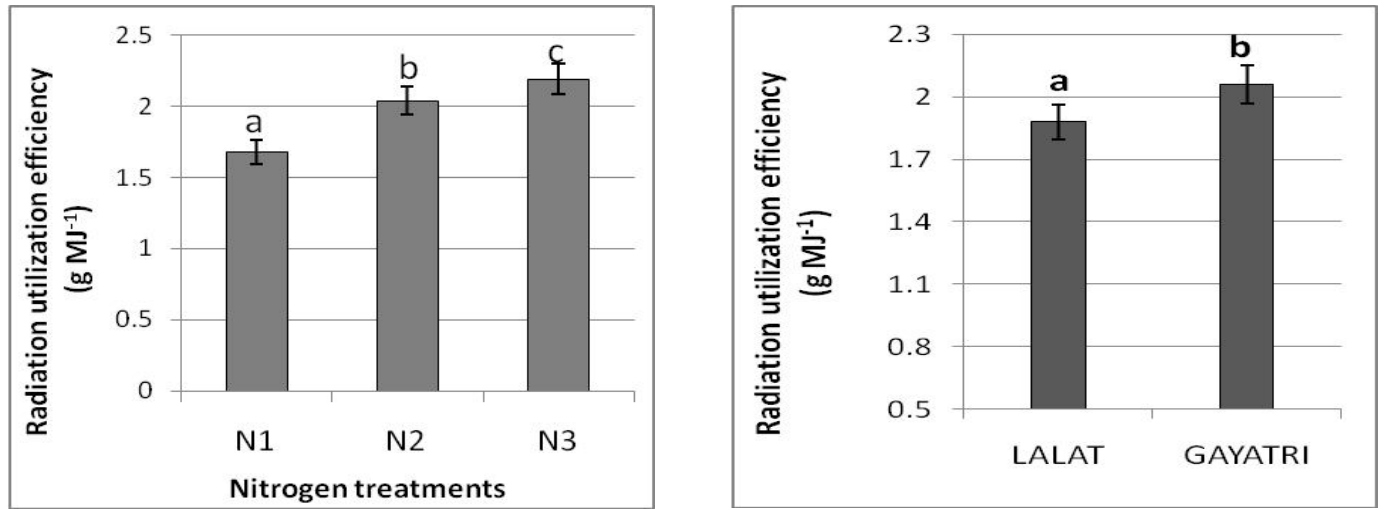

Fig. 5: Radiation utilization efficiency (in terms of total above ground biomass) in rainfed rice as varied by varieties and nitrogen treatments
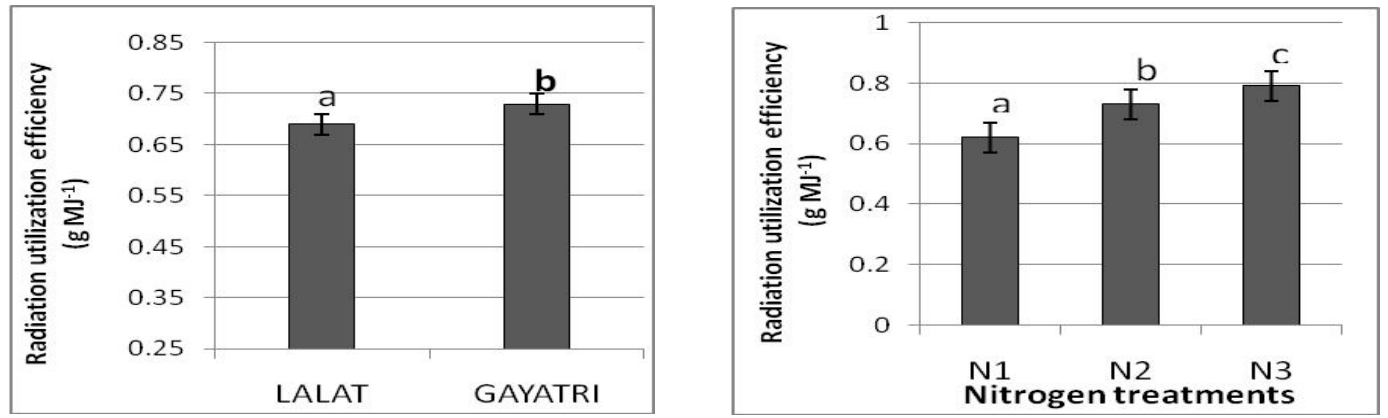

Fig. 6: Radiation utilization efficiency (in terms of grain yield) in rainfed rice as varied by varieties and nitrogen treatments value of 0.87 .

The year of study had no significant effects on RUE but cultivar differences in RUE were significant. Among varieties, 'Lalat' was less efficient in use of radiation and registered lower radiation utilization efficiency of $1.88 \mathrm{gMJ}$ ${ }^{1}$ in terms of AGDM accumulation (RUEbio) as compared to 
other Variety, 'Gayatri' (Fig.5). This variety used radiation more efficiently and recorded RUEbio of $2.06 \mathrm{~g} \mathrm{MJ}^{-1}$. Significant differences were found in RUEbio among N treatments. High dose of $\mathrm{N}$ increased RUE significantly across the varieties and seasons, mean RUEbio vales were computed as 1.68, 2.04 and $2.19 \mathrm{~g} \mathrm{MJ}^{-1}$ for $\mathrm{N}_{1}\left(50 \mathrm{~kg} \mathrm{~N} \mathrm{ha}^{-1}\right)$, $\mathrm{N}_{2}\left(100 \mathrm{~kg} \mathrm{~N} \mathrm{ha}^{-1}\right)$ and $\mathrm{N}_{3}\left(130 \mathrm{~kg} \mathrm{~N} \mathrm{ha}^{-1}\right)$ treatments, respectively.

\section{Radiation utilization efficiency in terms of grain yield (RUEgy)}

Fig. 6 shows the effect of treatments on radiation use efficiency for grain yield (RUEgy) and similar trend was observed in this case also like RUEbio. Year effects were non-significant on RUEgy. In terms of varieties the values of RUEgy recorded were 0.69 and $0.73 \mathrm{~g} \mathrm{MJ}^{-1}$ in 'Lalat' and 'Gayatri' variety, respectively. Effects of nitrogen were significant, averaged over years and varieties, $\mathrm{N}_{3}$ treatment recorded $0.79 \mathrm{~g} \mathrm{MJ}^{-1}$ RUEgy followed by $2\left(0.73 \mathrm{gMJ}^{-1}\right)$ and $\mathrm{N} 1\left(0.62 \mathrm{~g} \mathrm{MJ}^{-1}\right)$. The minimum values of mean RAUbio and RUEgywere registered from plots fertilized with $50 \mathrm{~kg} \mathrm{~N}^{-}$ ${ }^{1}(\mathrm{~N} 1)$, which might be attributed to lower biomass and grain yield in those plots. Interaction between cultivar and nitrogen rate were found to be non-significant.

\section{Evaporative fraction and partition of evapotranspiration}

Seasonal variation of evaporative fraction (EF) was computed and shown in Fig. 7 for both the varieties. The ratio of the latent heat flux to the available energy or evaporative fraction was found to be $79-82 \%$ in different cultivars and seasons. Daily transpiration ( $T$ ) and evaporation rate (E) were derived by using equation (4) and results are presented in Fig. 8 (a \& b) for Lalat and Gayatri, (pooled data of two years). As expected from the equation, E exceeded $T$ in the early growth stage (until 30 days after transplanting) and $\mathrm{T}$ dominated afterwards. Seasonal trend of $\mathrm{T}$ showed a gentle broad peak from maximum tillering stage to the heading stage. Bouman etal. (2005) also found that transpiration rate at wetland rice generally increased consistently upto heading stage and then followed a decline trend, maximum transpiration occurred at the heading to dough stage. In this study $\mathrm{T}$ and $\mathrm{E}$ were estimated as $68 \%$ and $32 \%$, respectively of the seasonal ET. Some earlier workers also showed that $\mathrm{T}$ accounted for $60-70 \%$ in the growing period of irrigated rice (Bouman etal. 2005). In Japan Maruyama and Kuwagata (2010) estimated larger fraction of E, ranging from 52 to $64 \%$ suggested that the fraction changes with transplanting date.

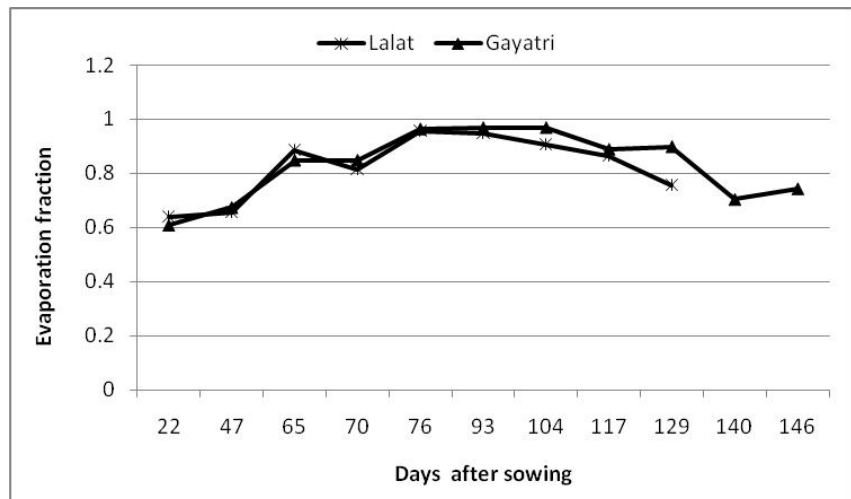

Fig. 7: Evaporative fraction of rice (cv. Lalat and Gayatri) during two growth seasons
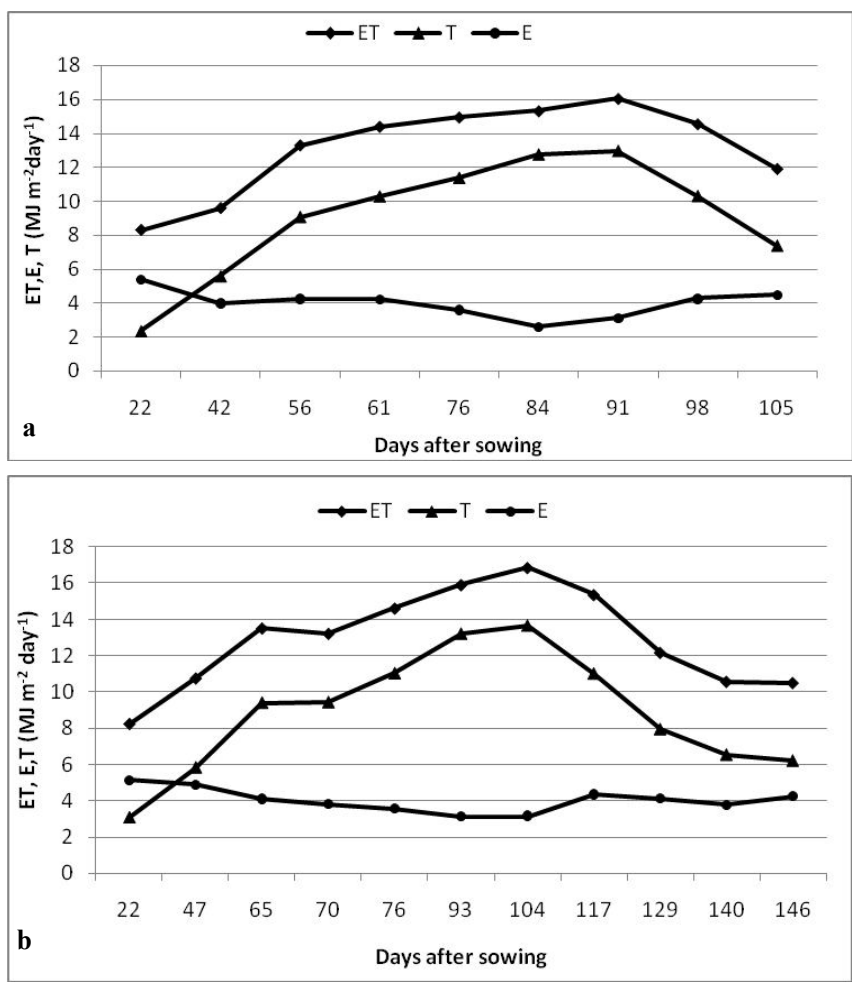

Fig. 8: Partitioning of evapotranspiration in cultivar (a) 'Lalat' and (b) Gatatri (pooled data of 2008 and 2009)

\section{CONCLUSION}

The accumulative above ground total biomass production was linearly correlated with the accumulative absorbed photosynthetically active radiation (APAR) and also with radiation utilization efficiency. Among the two varities 'Gayatri' was more efficient in utilizing PAR and hence recorded higher RUE in terms of total above ground biomass and grain yield. Averaged over years and varieties, nitrogen levels significantly affected the amount of RUE in terms of biomass and yield. Therefore, to obtain optimum RUE, proper $\mathrm{N}$ management needs to be carried out in rice field when the crop is grown in rainy season. The increase 
in RUE with higher level of nitrogen was due to better crop growth, which produced maximum plant height, LAI and total dry matter. The latent heat flux (LE) was largely found to be varied with leaf area index (LAI) which showed peak when LAI was maximum. As expected from the equation, E exceeded $\mathrm{T}$ in the early growth stage (until 30 days after transplanting) and T dominated afterwards. Seasonal trend of $\mathrm{T}$ showed a gentle broad peak from maximum tillering stage to the heading stage and particularly of evapotranspiration (ET) indicated that about $70-80 \%$ of seasonal ET came from transpiration.

\section{REFERENCES}

Bouman, B. A. M., Peng, S., Castaneda, A. R. and Visperas, R. M., (2005). Yield and water use of irrigated tropical aerobic rice systems. Agric. Water Manag., 74: 87-105.

Conner, D. J., Jones, T. R., and Palla, J. A., (1985). Response of Sunflower to strategies of irrigation. I. Growth, yield and efficiency of water use. Field Crop Res., 10: 15-36.

Figuerola, P. I., and Berlinger, P. R., (2006). Characterization of the surface layer above a row crop in the presence of local advection, Atmosfera, 19: 75-108.

Gallaghar, J. N. andBiscoe, P. V., (1978). Radiation absorption, growth and yield of cereals. J. Agric. Sci, Camb., 91: 4760 .

Gregory, P. J., Tennant, D. and Belford, R. K., (1992). Root and shoot growth and water and light use efficiency of barley and wheat crop grown on a shallow duplex soil in Mediterranean-type environment. Aus. J. Agric. Res., 43: $555-573$.

Gomez, K.A. and Gomez,A.A.,(1984). StatisticalProcedures for Agricultural Research with Spatial Emphasis on Rice. Philippines, International Rice research.

Hughes, G. and Keatinge, J. D. H., (1983). Solar radiation interception, dry matter production and yield in pigeonpea (Cajanus cajan(L.) Millspaugh). Field Crops Res., 6: 171-178.

Kailashnathan, K. and Sinha, S. K., (1984). Radiation, productivity potential and actual biology yield at Delhi, Proc. Indian Natr. Sci. Acad., B-46, No. 5: 688-693.

Kar, G., (2005). Radiation interception, rainwater and radiation utilization efficiency study of legume based intercropping in rainfed upland rice area of eastern India. $J$. Agrometeorol., 7(1): 84-89.

Kiniry, J. R., Jonnes, C. A., O' Toole, J. C., Blanchet, R., Cabelguenne, M. and Spanel, D. A., (1989). Radiationuse efficiency in biomass accumulation prior to grainfilling for five grain crop spices, Field Crop Res., 20: 5154.

Maruyama,A. and Kuwagata, T.,(2010). Coupling land surface and crop models to estimate the effects of changes in the growing season on energybalance and water use of rice paddies. Agric. Forest Meteorol., 150:919-930.

Monteith, J. L., (1972). Solar radiation and productivity in tropical ecosystem. J. Appl. Ecol., 9: 747-766.

Monteith, J. L., (1977). Climate and the efficiency of the Royal Society of London B281: 277-297.

Monteith, J. L., (1994). Validity of the correlation between intercepted radiation and biomass. Agric. Forest Meteorol., 68: 213-220.

Pitman, J.I. 2000. Absorption of photosynthetically active radition, radiation use efficiency and spectral reflectance of Bracken [Pteridium aquilinum (L.) Kuhn] canopies, Annals of Botany, 85 (Supplement B): 101-111: 2000.

Robertson, M. G., Silim, S., Chauhan, Y.S. andRanganathan, R., (2001). Predicting growth and development of pigeonpea: biomass accumulation and partitioning. Field Crop Res., 70: 89-100.

Russel, G., Jarvis, P.G., and Monteith, J. L., (1989). Absorption of radiation by canopies and stand growth. In: Palnt canopies: their growth, form and function, Russel, G., Marshall, B. and Jarvis, P. G., (eds.) Cambridge: Cambridge UniversityPress, 21-39.

Sivakumar, M. K. V. and Viramani, S.M., 1984. Crop productivity in relation to interception of photosynthetically active radiation. Agric. For. Meteorol., 31: 131-141.

Uchijima, Z., (1976). Maize and rice. In: Vegetation and the Atmosphere, vol. 2. Case Studies, Monteith, J.L., (Editor), Academic Press: London 33-64.

Uchijima,Z.,(1961). On characteristics of heat balance of water layer under paddy plant cover. Bulletin Notat. Institute Agric. Sci., A8: 243-265. 